\title{
Hydrogen-Ion Potential of Antibiotics According to the Environment Factors Temperature and Luminosity ${ }^{1}$
}

\author{
Renata Maria Coelho Crepaldi² \\ Cíntia Monteiro ${ }^{3}$ \\ Maria Angélica Sorgini Peterlini ${ }^{4}$ \\ Mavilde da Luz Gonçalves Pedreira ${ }^{5}$
}

\begin{abstract}
The objective of this experimental study was to measure the $\mathrm{pH}$ of antibiotics administered by intravenous infusion - ceftriaxone sodium, vancomycin hydrochloride, metrodinazole, penicillin $\mathrm{G}$ potassium and amikacin sulfate - after reconstitution with sterile water and dilution with $\mathrm{NaCl} 0.9 \%$ or dextrose $5 \%$ in water, according to temperature and luminosity of the environment. The results showed that variation in the drugs' $\mathrm{pH}$ was less than 1.0 value and that some antibiotics remained acidic after dilution and maintained this chemical profile in all situations studied, suggesting that the studied environmental factors did not change the solutions' acid base characteristic. Some $\mathrm{pH}$ values measured characterize risk for the development of chemical phlebitis and infiltration, and it is important for clinical practice to emphasize the profile of intravenous solutions of antibiotics, considering method of dilution, and time to infusion.
\end{abstract}

Descriptors: Pediatric Nursing; Infusions Intravenous; Hydrogen-Ion Concentration; Drug Stability; Safety.

\footnotetext{
${ }^{1}$ Supported by CNPq Process \#476295/2004-1 and \#502382/2007-4.

${ }^{2}$ RN. E-mail: recrepaldi@hotmail.com.

${ }^{3}$ Nursing Undergraduate Student, Departamento de Enfermagem, Universidade Federal de São Paulo, SP, Brazil. Scholarship holder, Basic Scientific Program CNPq. E-mail: cintiamonteiromsp@hotmail.com.

${ }^{4}$ Ph.D. in Nursing, Adjunct Professor, Departamento de Enfermagem, Universidade Federal de São Paulo, SP, Brazil. E-mail: maria. angelica@unifesp.br.

${ }^{5}$ Ph.D. in Nursing, Adjunct Professor, Departamento de Enfermagem, Universidade Federal de São Paulo, SP, Brazil. E-mail: mpedreira@ unifesp.br.
}

Corresponding Author:

Mavilde da Luz Gonçalves Pedreira Universidade Federal de São Paulo Rua Napoleão de Barros, 754 sala 112 Vila Clementino 


\title{
Potencial hidrogeniônico de antimicrobianos, segundo os fatores ambientais temperatura e luminosidade
}

O objetivo deste estudo experimental foi medir o pH dos antibióticos de administração intravenosa ceftriaxona sódica, cloridrato de vancomicina, metronidazol, penicilina G potássica e sulfato de amicacina, após reconstituição com água destilada e diluição com $\mathrm{NaCl} 0,9 \%$, ou soro glicosado $5 \%$, considerando a influência da temperatura e luminosidade ambientais, assim como do tempo de exposição, no comportamento químico desses fármacos. Os resultados demonstraram variações que não ultrapassaram 1,0 valor de $\mathrm{pH}$ e que alguns antimicrobianos, eminentemente ácidos após a diluição, mantiveram esse comportamento em todas as situações estudadas, não sugerindo a influência de fatores ambientais no comportamento químico das soluções. Como alguns valores de $\mathrm{pH}$ encontrados podem contribuir para o desenvolvimento de flebite química e infiltração, é importante enfatizar para a prática clínica em saúde, a necessidade de conhecer as características das soluções de infusão intravenosa, considerando tipo de diluição e tempo de infusão.

Descritores: Enfermagem Pediátrica; Infusões Intravenosas; Concentração de Íons de Hidrogênio; Estabilidade de Medicamentos; Segurança.

\section{Potencial hidrogenionico de antimicrobianos, según los factores ambientales de temperatura y luminosidad}

\begin{abstract}
El objetivo de este estudio experimental fue medir el pH de los antibióticos de administración intravenosa ceftriaxona sódica, clorhidrato de vancomicina, metronidazol, penicilina G potásica y sulfato de amikacina, después de reconstitución con agua destilada y dilución con $\mathrm{NaCl}$ a $0,9 \%$, o suero glucosado a $5 \%$, considerando la influencia de la temperatura y luminosidad ambientales, así como el tiempo de exposición, en el comportamiento químico de esos fármacos. Los resultados demostraron variaciones que no ultrapasaron 1,0 (valor de $\mathrm{pH}$ ) y que algunos antimicrobianos, eminentemente ácidos después de la dilución, mantuvieron ese comportamiento en todas las situaciones estudiadas, no sugiriendo la influencia de factores ambientales en el comportamiento químico de las soluciones. Considerando que algunos valores de $\mathrm{pH}$ encontrados pueden contribuir para el desarrollo de flebitis química e infiltración, es importante enfatizar que para la práctica clínica en salud, existe la necesidad de conocer las características de las soluciones de infusión intravenosa, considerando el tipo de dilución y el tiempo de infusión.
\end{abstract}

Descriptores: Enfermería Pediátrica; Infusiones Intravenosas; Concentración de Iones de Hidrógeno; Estabilidad de Medicamentos; Seguridad.

\section{Introduction}

Intravenous (IV) medication administration is highly relevant in clinical practice for the treatment of patients with acute or chronic conditions and for the prophylaxis of some diseases. Among evidence of the large-scale use of this treatment in the pediatric population, a study carried out with children hospitalized at pediatric units of a Brazilian hospital found the daily administration of 4.4 doses $^{(1)}$.
Antibiotics stand out among the most used drugs in children. Due to the lack of a pharmaceutical form for the pediatric age range, IV administration of these drugs requires dilution in small volume and prolonged infusion time, at speeds of up to tens of milliliters per hour, so as to avoid hypervolemia, heart failure and toxicity ${ }^{(2)}$. Inquiries arise, however, about maintaining these drugs' stability in hospital units' environmental conditions. 
The stability of a drug is a critical element for appropriate medication administration, as both the appropriateness and safety of therapy can be affected in case of pharmacological instability(3). A drug is considered stable in a solution if at least $90 \%$ of its concentration does not suffer decomposition ${ }^{(4)}$. The term pharmacological instability is applied to continuing and irreversible chemical reactions that result in different substances or products of degradation, which can be both therapeutically inactive and capable of causing toxic effects. Among different degradation routes, drugs can suffer hydrolysis, oxidation and reduction(3).

The stability of drugs in solutions can be affected by many factors, such as environmental light, temperature, and the solution's final concentration. Many drugs' degradation is catalyzed by $\mathrm{pH}$ extremes, with reactions being affected by the presence of hydrogen or hydroxile ions. Drugs' reaction rates are generally lower in intermediary than in high or low $\mathrm{pH}$ values. This evidences the importance of maintaining a constant hydrogen-ion concentration in the solution. The consequence of an altered $\mathrm{pH}$ can be both decreased chemical stability or precipitation of one or more drugs. Moreover, pharmacological instability can lead to alterations in hydrogen-ion concentration(4).

A solution's $\mathrm{pH}$ represents the concentration level of this solution's hydrogen ions. By convention, the $\mathrm{pH}$ measurement unit equals the negative logarithm of the hydrogen-ion concentration in a solution. The concentration of this ion in liquid water at $25^{\circ} \mathrm{C}$ is $10^{-}$ ${ }^{7} \mathrm{~mol} / \mathrm{L}$. As hydrogen ions are neutralized by hydroxile ions at this concentration, the neutral medium has a $\mathrm{pH}$ equal to seven, the acid medium, between zero and seven and the base medium, between seven and fourteen. Each unit decrease in $\mathrm{pH}$ represents a tentime addition in the concentration of hydrogen ions ${ }^{(5-6)}$.

This research aims to provide tools for safe IV therapy practice in pediatrics, considering the lack of studies on the $\mathrm{pH}$ of antibiotics solution, submitted to environmental conditions verified in clinical practice. Thus, the goal is to assess the $\mathrm{pH}$ of five antibiotics for IV administration, considering the influence of external factors like environmental light and temperature during the time recommended for the IV infusion of these solutions.

\section{Purpose}

To measure the $\mathrm{pH}$ of five antibiotics after their reconstitution and dilution in $\mathrm{NaCl} 0.9 \%$ and dextrose
$5 \%$ in water, considering the influence of temperature, environmental light and exposure time to these factors.

\section{Material and method}

This experimental study was carried out after approval by the internal ethical review board at the university the authors are affiliated with. Data were collected at a laboratory between April and October 2007. The study hypothesis was that environmental temperature and light, as well as, exposure time to these factors, provoke alterations in the $\mathrm{pH}$ behavior of solutions with antimicrobial agents for IV administration.

The sample comprised the $\mathrm{pH}$ of five antimicrobials used in pediatric hospital units of the university where the study was carried out(1): ceftriaxone sodium, vancomycin hydrochloride, metrodinazole, penicillin G potassium and amikacin sulfate.

The following environmental conditions were considered: $\alpha$ - environmental temperature of $22^{\circ} \mathrm{C}$ and non-exposure to light (control); $\beta$ - environmental temperature of $22^{\circ} \mathrm{C}$ and exposure to light; $\gamma$ environmental temperature of $30^{\circ} \mathrm{C}$ and non-exposure to light and $\theta$ - environmental temperature of $30^{\circ} \mathrm{C}$ and exposure to light.

For each situation, eight moments were chosen for $\mathrm{pH}$ measurement: immediately after reconstitution in sterile water or liquid presentation; $24 \mathrm{~h}$ after reconstitution in refrigerated conditions; t0 - immediately after dilution in sodium chloride $0.9 \%$ or dextrose $5 \%$; 11 - five minutes after dilution; t2 - 30 minutes after dilution; t3 - 60 minutes after dilution; t4 - 120 minutes after dilution and $\mathrm{t} 5 \mathrm{-}-24 \mathrm{~h}$ after dilution.

The drugs' reconstitution and dilution was performed according to the institution's nursing protocol. After one hour of exposure to the environmental condition under analysis, the powder drugs were reconstituted with sterile water, resulting in concentrations of $100 \mathrm{mg} / \mathrm{mL}$ for ceftriaxone sodium and vancomycin hydrochloride and $500000 \mathrm{U} / \mathrm{mL}$ for penicillin $\mathrm{G}$ potassium. After the reconstitution, a sample was taken from the vial to verify the $\mathrm{pH}$. Another sample was used to dilute the antibiotics. The remainder was kept in the vial for refrigeration and $\mathrm{pH}$ was measured again after $24 \mathrm{~h}$ of refrigeration.

As metrodinazole and amikacin sulfate are distributed in liquid form, $\mathrm{pH}$ values were obtained from the commercial solution at concentrations of $5 \mathrm{mg} / \mathrm{mL}$ and $250 \mathrm{mg} / \mathrm{mL}$, respectively.

All drugs were diluted in $\mathrm{NaCl} 0.9 \%$ and dextrose $5 \%$ (SG 5\%), at different times. The final concentration 
of each drug was $5 \mathrm{mg} / \mathrm{mL}$ for amikacin sulfate, metrodinazole and vancomycin hydrochloride, 20mg/ $\mathrm{mL}$ for ceftriaxone sodium and 50 000U/mL for penicillin $\mathrm{G}$ potassium. The final volume of the solution was set at $20 \mathrm{~mL}$ for all drugs. The only non-diluted drug was metrodinazole, as its pharmaceutical form has the ideal concentration for IV administration i.e., according to the manufacturer, $5 \mathrm{mg} / \mathrm{mL}$.

After the drugs had been diluted and exposed to environmental situations, a sample of the solution was removed from the syringe and stored in a glass Becker to verify $\mathrm{pH}$ values at intervals from to to $\mathrm{t} 5$.

A digital ExStik ${ }^{\mathrm{TM}} \mathrm{PH} 100$ meter manufactured by Extech $^{\circledR}$ (USA) was used. This is a millivoltmeter linked to an electrode selective for hydrogen ions, with a scale that converts the voltage of the electrode into $\mathrm{pH}$ units(7). The accuracy of the meter covers an interval up to \pm 0.01 on the $\mathrm{pH}$ scale. Calibration was performed according to the manufacturer's instructions ${ }^{(8)}$.

Environmental light was obtained through white light fluorescent lamps. Two digital thermometers, model 7429, brand TFA ${ }^{\circledR}$ Dostmann (Reicholzhein, Baden-Württemberg, Germany) were used for thermal control of the laboratory environment.
The $\mathrm{pH}$ values of antimicrobials in each environmental situation were analyzed descriptively, using means and standard deviation, shown in tables and pictures and discussed with regard to changes in $\mathrm{pH}$ values over time, problems for medication stability and intravenous complications described in literature.

\section{Results}

Measurements resulted in $264 \mathrm{pH}$ values. Laboratory temperature was successfully controlled, even when the solutions were exposed to the study conditions for 24 hours, with a $1^{\circ} \mathrm{C}$ rise in all conditions. Refrigerator temperature, remained within the expected range, with an average of $4.45^{\circ} \mathrm{C}$.

As mentioned, three antimicrobials were submitted to reconstitution. Immediately after the procedure, the most acid antimicrobial was vancomycin hydrochloride, with the lowest $\mathrm{pH}$ value (2.72) in $\mathrm{y}$. The least acid $\mathrm{pH}$ was for ceftriaxone sodium in $\beta$ (7.05). After 24 hours of refrigeration, no relevant changes in hydrogen ion concentration were found. The highest standard deviation was observed for penicillin $G$ potassium in situation $\beta$ : $6.64 \pm 0.177$ (Table 1).

Table 1 - Hydrogen-ion potential $(\mathrm{pH})$, mean and standard deviation of antimicrobial agents' $\mathrm{pH}$ immediately after reconstitution with sterile water and 24-hour storage in refrigerator, according to temperature and environmental light. São Paulo, 2007

\begin{tabular}{|c|c|c|c|c|c|}
\hline \multirow{2}{*}{ Antimicrobial } & \multirow{2}{*}{ Condition } & \multicolumn{4}{|c|}{$\mathbf{P h}$} \\
\hline & & Immediately after reconstitution & 24 hours & Mean & Standard deviation \\
\hline \multirow[t]{4}{*}{ Ceftriaxone sodium } & $\alpha$ & 6.96 & 6.95 & 6.96 & 0.007 \\
\hline & $\beta$ & 7.05 & 6.89 & 6.97 & 0.113 \\
\hline & $\gamma$ & 6.48 & 6.41 & 6.45 & 0.049 \\
\hline & $\theta$ & 6.44 & 6.49 & 6.47 & 0.035 \\
\hline Vancomycin & $\alpha$ & 2.91 & 2.93 & 2.92 & 0.014 \\
\hline \multirow[t]{3}{*}{ hydrochloride } & $\beta$ & 2.92 & 2.95 & 2.94 & 0.021 \\
\hline & $\gamma$ & 2.72 & 2.72 & 2.72 & 0 \\
\hline & $\theta$ & 2.96 & 2.92 & 2.94 & 0.028 \\
\hline \multirow[t]{4}{*}{ Penicillin G potassium } & $\alpha$ & 6.76 & 6.63 & 6.70 & 0.092 \\
\hline & $\beta$ & 6.76 & 6.51 & 6.64 & 0.177 \\
\hline & $\gamma$ & 6.58 & 6.55 & 6.57 & 0.021 \\
\hline & $\theta$ & 6.68 & 6.66 & 6.67 & 0.014 \\
\hline
\end{tabular}

A small variation in the $\mathrm{pH}$ of all drugs diluted in $\mathrm{NaCl} 0.9 \%$ was observed, with greater modifications after 24 hours than at other times. Increases in $\mathrm{pH}$ values were observed for all antibiotics, except for amikacin sulfate at $30^{\circ} \mathrm{C}$. Vancomycin hydrochloride and amikacin sulfate showed the most acid $\mathrm{pH}$ values: 3.10 and 4.94, respectively. The least acid values came from ceftriaxone sodium and crystalline penicillin, with 6.88 and 6.17 , respectively (Figure 1 ). 

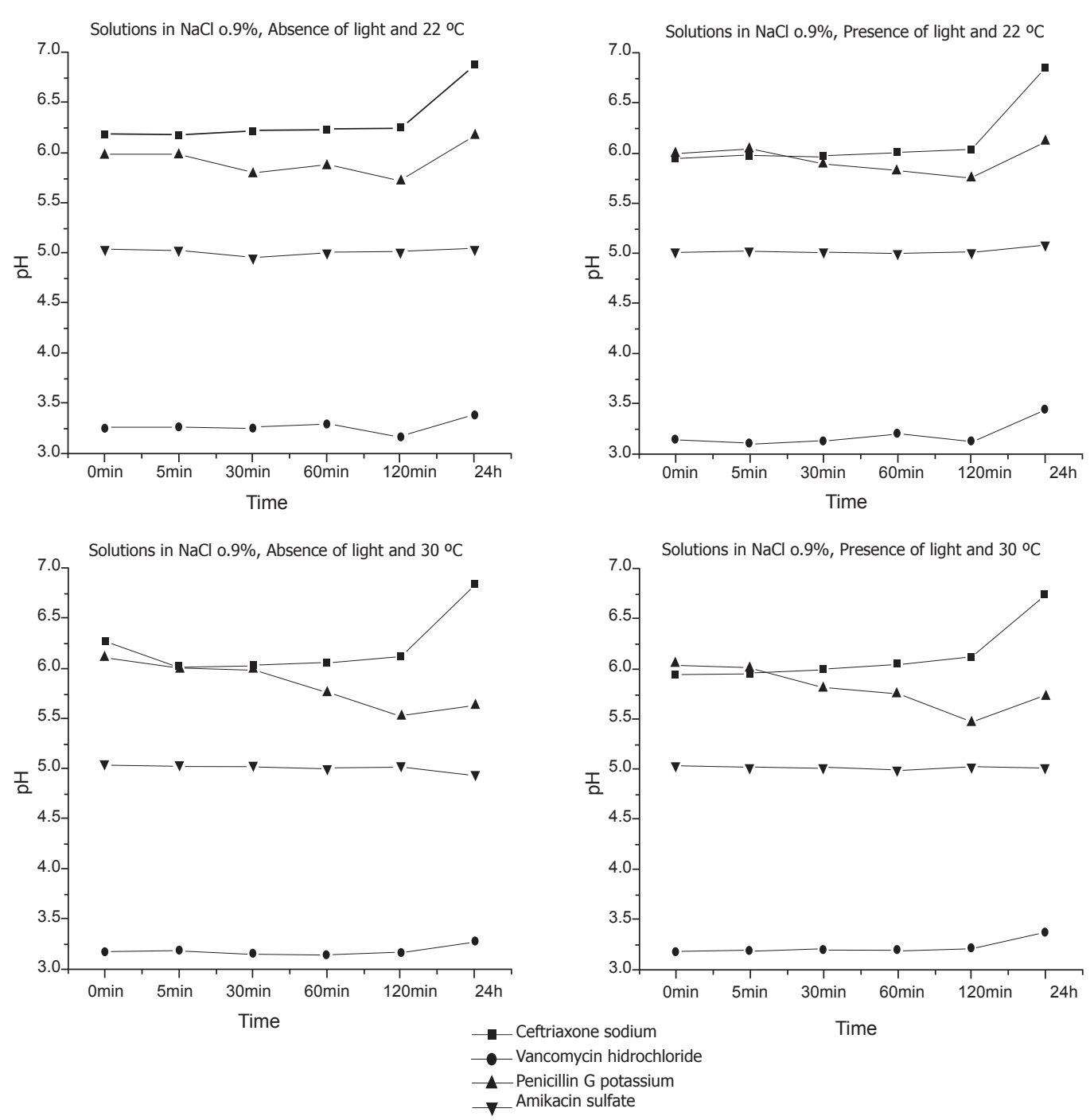

Figure 1 - Hydrogen-ion potential $(\mathrm{pH})$ of antimicrobial agents diluted in $\mathrm{NaCl} 0.9 \%$, according to environmental condition and exposure time. São Paulo, 2007

Using dextrose $5 \%$ for dilution, modifications are observed in some antibiotics, mainly at 24 hours of exposure. At that moment, the $\mathrm{pH}$ values of ceftriaxone sodium and vancomycin hydrochloride increased in all conditions and that of amikacin sulfate in conditions without exposure to light. For penicillin $\mathrm{G}$ potassium, $\mathrm{pH}$ values went down in all situations. Like when diluted in $\mathrm{NaCl} 0.9 \%$, vancomycin hydrochloride and amikacin sulfate showed the most acid $\mathrm{pH}$ values: 3.11 and 5.01, respectively. The highest values were found for ceftriaxone sodium and crystalline penicillin: 7.01 and

\subsection{4 , respectively (Picture 2 ).}

It should be observed that $\mathrm{pH}$ values of penicillin $\mathrm{G}$ potassium increase after 24 hours when diluted in $\mathrm{NaCl}$ $0.9 \%$ in all situations. When diluted in SG5\%, however, it becomes more acid after 24 hours. The $\mathrm{pH}$ value of vancomycin hydrochloride remained quite acid, even after dilution.

Small variations in $\mathrm{pH}$ values of metrodinazole occurred over time, with considerable $\mathrm{pH}$ after 24 hours of exposure in all environmental conditions (Picture 3). 

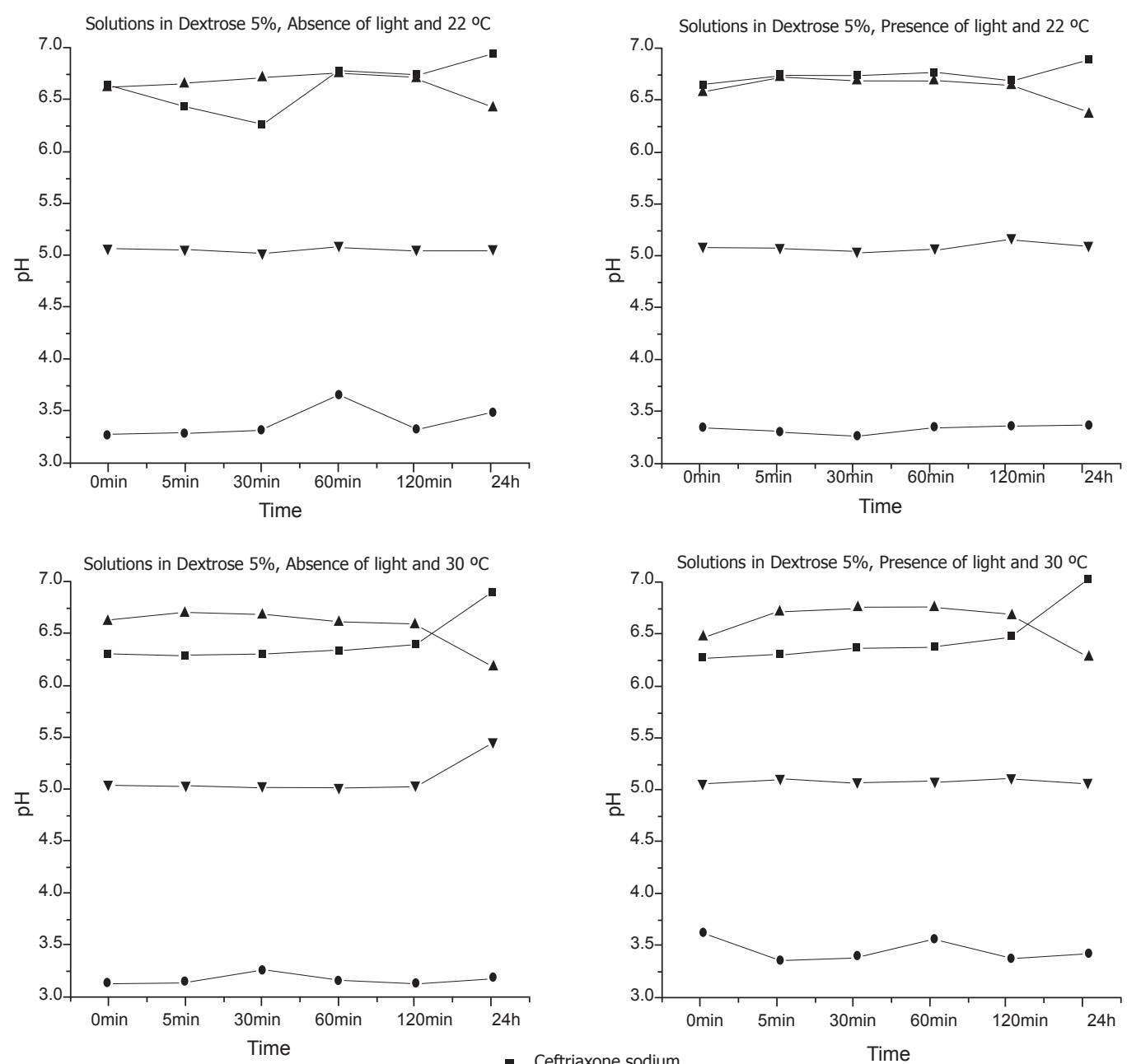

- Ceftriaxone sodium

- Vancomycin hidrochloride

^-Penicillin $\mathrm{G}$ potassium

$\rightarrow$ Amikacin sulfate

Figure 2 - Hydrogen-ion potential $(\mathrm{pH})$ of antimicrobial agents diluted in dextrose 5\%, according to environmental condition and exposure time. São Paulo, 2007

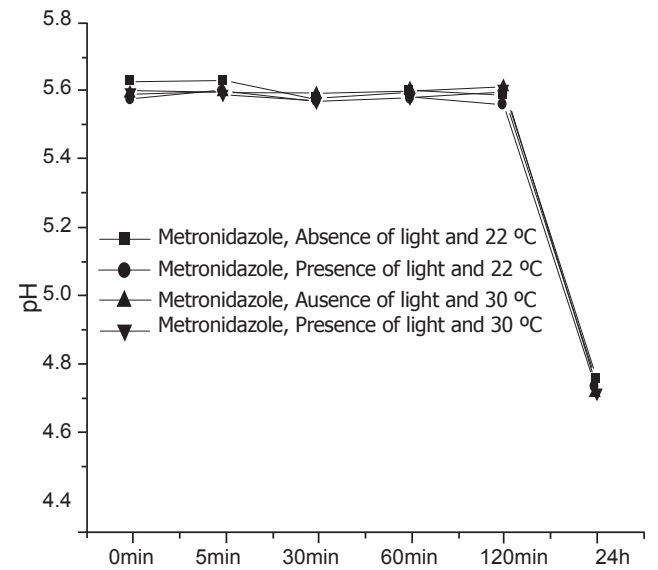

Figure 3 - Hydrogen-ion potential $(\mathrm{pH})$ of metrodinazole, according to environmental condition and exposure time. São Paulo, 2007
The individual analysis of each drug diluted in physiological saline solution shows the mean and standard deviation of the antibiotics in the four situations as follows: ceftriaxone sodium (6.20 \pm 0.311$)$, vancomycin hydrochloride $(3.21 \pm 0.080)$, penicillin $G$ potassium $(5.87 \pm 0.185)$ and amikacin sulfate $(5.01 \pm 0.030)$. After dilution in SG5\%, the following values are observed: ceftriaxone sodium $(6.56 \pm 0.212)$, vancomycin hydrochloride $(3.33 \pm 0.087)$, penicillin $G$ potassium $(6.60 \pm 0.158)$ and amikacin sulfate (5.08 \pm 0.064$)$ And, finally, for metrodinazole, the mean value was $5.50 \pm 0.350$. Moreover, data demonstrate that, when diluted in SG5\%, all antimicrobials showed higher mean $\mathrm{pH}$ values than what was found for the other thinner (Table 2). 
It should be highlighted that, although analogue $\mathrm{pH}$ values were to be expected for the drugs in commercial form, variations in $\mathrm{pH}$ values were observed, even when the drugs came from the same manufacturer (Pictures 1 and 3).

Table 2 - Mean and standard deviation in $\mathrm{pH}$ of antimicrobial agents at six moments after dilution, according to environmental condition and type of dilution. São Paulo, 2007

\begin{tabular}{|c|c|c|c|c|c|}
\hline \multirow{3}{*}{ Antimicrobial } & \multirow{3}{*}{ Condition } & \multicolumn{4}{|c|}{$\mathrm{pH}$} \\
\hline & & \multicolumn{2}{|c|}{$\mathrm{NaCl} 0.9 \%$} & \multicolumn{2}{|c|}{ Dextrose $5 \%$} \\
\hline & & Mean & Standard deviation & Mean & Standard deviation \\
\hline \multirow[t]{4}{*}{ Ceftriaxone sodium } & $\alpha$ & 6.32 & 0.276 & 6.63 & 0.244 \\
\hline & $\beta$ & 6.13 & 0.351 & 6.74 & 0.082 \\
\hline & $\gamma$ & 6.22 & 0.315 & 6.42 & 0.241 \\
\hline & $\theta$ & 6.13 & 0.302 & 6.46 & 0.280 \\
\hline Vancomycin & $\alpha$ & 3.27 & 0.071 & 3.39 & 0.148 \\
\hline \multirow[t]{3}{*}{ hydrochloride } & $\beta$ & 3.19 & 0.129 & 3.32 & 0.041 \\
\hline & $\gamma$ & 3.18 & 0.047 & 3.15 & 0.051 \\
\hline & $\theta$ & 3.21 & 0.073 & 3.44 & 0.109 \\
\hline \multirow[t]{4}{*}{ Penicillin G potassium } & $\alpha$ & 5.92 & 0.160 & 6.64 & 0.116 \\
\hline & $\beta$ & 5.93 & 0.137 & 6.61 & 0.126 \\
\hline & $\gamma$ & 5.83 & 0.233 & 6.55 & 0.193 \\
\hline & $\theta$ & 5.80 & 0.211 & 6.59 & 0.196 \\
\hline \multirow[t]{4}{*}{ Amikacin sulfate } & $\alpha$ & 5.01 & 0.034 & 5.06 & 0.023 \\
\hline & $\beta$ & 5.02 & 0.029 & 5.08 & 0.041 \\
\hline & $\gamma$ & 5.01 & 0.040 & 5.09 & 0.172 \\
\hline & $\theta$ & 5.01 & 0.017 & 5.07 & 0.021 \\
\hline
\end{tabular}

\section{Discussion}

Both phlebitis and infiltration are commonly identified complications in peripheral intravenous therapy. Phlebitis can be classified as chemical, mechanical or infectious. The cause of chemical phlebitis can derive, among other factors, from extreme $\mathrm{pH}$ values, leading to an inflammatory response in the inner layer of the vein that can lead to infiltration, edema, thrombosis and cell death(6).

A randomized clinical trial involving children hospitalized at a Brazilian institution showed that 55.3\% of peripheral venous catheters were removed due to infiltration and $4.7 \%$ due to phlebitis ${ }^{(9)}$.

The range of $\mathrm{pH}$ values that entails risks for IV therapy complications is below 5.5 and above $8.0^{(10)}$. In this research, vancomycin hydrochloride and amikacin sulfate presented $\mathrm{pH}$ values below 5.5 after dilution. Metrodinazole also showed risky $\mathrm{pH}$ values, but only after 24 hours of exposure.

In nursing practice, professionals are often unaware of drugs' $\mathrm{pH}$, exposing patients to complications by administering more concentrated solutions in less time than recommended, due to the need for fluid restriction in some cases. Besides causing changes in the IV administration site, extreme $\mathrm{pH}$ values can catalyze many drugs' degradation. This also derives from other factors, including temperature, environmental light and concentration of the solution. Drug instability can also lead to $\mathrm{pH}$ value alterations ${ }^{(3)}$.

Light activates photodegradation reactions, such as oxidation and hydrolysis. Hence, the stronger a light source and/or the closer the photosensitive drug is placed to that source, the higher the degradation level will be ${ }^{(3)}$. During IV administration of metrodinazole, protection against light is no source of concern in the hospital environment ${ }^{(11)}$. In this research, metrodinazole showed low variation in the concentration of hydrogen ions when exposed to light.

An experimental research revealed that the $\mathrm{pH}$ of penicillin $\mathrm{G}$ potassium at $5000 \mathrm{U} / \mathrm{mL}$ presented minimal variations after adding saline (mean 6.04) and dextrose (mean 5.60), solutions at 4,25 and $37^{\circ} \mathrm{C}^{(12)}$. When diluted in saline solution, the mean $\mathrm{pH}$ value of penicillin $\mathrm{G}$ potassium was close to literature values (5.87). When diluted in dextrose, however, the value was higher (6.60).

In general, increases in environmental temperature influence solutions' degradation rate, causing $\mathrm{pH}$ 
modifications and, consequently, pharmacological instability. Literature describes penicillin $\mathrm{G}$ potassium and cephalosporins as labile to heat ${ }^{(3)}$. This was observed for the penicillin, with a higher standard deviation in situations at $30^{\circ} \mathrm{C}$.

Although ceftriaxone sodium showed low lability to high temperature, important increase in $\mathrm{pH}$ occurred after 24 hours of exposure in all situations and in both thinners. Another experiment evidenced that this antimicrobial at $100 \mathrm{mg} / \mathrm{mL}$ in sterile water remained stable for 40 days at $4^{\circ} \mathrm{C}^{(13)}$. The analysis of $\mathrm{pH}$ variations in the same concentration of ceftriaxone sodium, after reconstitution and storage in a refrigerator for 24 hours, showed hardly considerable changes, revealing no reactions that would modify $\mathrm{pH}$ values.

Due to the lack of a pharmaceutical form for the pediatric age range, the reconstituted solutions are stored in refrigerated conditions and concentrated drugs are diluted in different volumes and solutions for IV infusion. Questions arise, however, about refrigeration time until the next administration and stability after dilution and IV administration in uncontrolled environmental situations ${ }^{(1)}$.

At some institutions, the reconstituted drugs are stored in refrigerators that sometimes do not maintain the recommended temperature between $4^{\circ} \mathrm{C}$ and $8^{\circ} \mathrm{C}^{(14)}$. These drugs are removed from the refrigerator different times, exposed to environmental temperature and returned to the refrigerator without knowledge about their stability. Besides ceftriaxone sodium, vancomycin hydrochloride and penicillin $\mathrm{G}$ potassium were also stored for 24 hours, with small variations in their $\mathrm{pH}$ values.

In this experiment, the antibiotics were diluted in recommended solutions, i.e. $\mathrm{NaCl} 0.9 \%$ and SG5\%, with $\mathrm{pH}$ values of 5.5 and between 3.5 and 6.5, respectively ${ }^{(10)}$. Antimicrobials in general are unstable in alkaline $(\mathrm{pH}$ above 8$)$ or acid ( $\mathrm{pH}$ below 4$)$ solutions ${ }^{(15)}$. Therefore, the used thinners do not represent risk for instability, but should be stored at temperatures below $25^{\circ} \mathrm{C}$ without freezing ${ }^{(11)}$.

Thus, the $\mathrm{pH}$ of each component in a mixture should be previously verified in order to avoid therapeutic harm and other complications ${ }^{(3)}$. When reconstituted, vancomycin hydrochloride showed $\mathrm{pH}$ values below 4, representing a risk factor for pharmacological instability for the solution stored until the next administration.

For practical purposes, it is important to plan IV therapy, to know drugs' physical-chemical characteristics, such as the hydrogen potential, and to determine the dilution method and infusion time, guaranteeing safe IV administration without complications.

\section{Conclusion}

The environmental situations that simulate clinical practice provoked changes in the antimicrobials' $\mathrm{pH}$ values of less than 1.0. Amikacin sulfate and vancomycin hydrochloride stand out as risky drugs for the development of local complications of intravenous therapy. In clinical practice, it is important to know the characteristics of IV infusion solutions, considering dilution type and infusion time. Therefore, it is fundamental for clinical health practice to continue this type of research, using other parameters to analyze the pharmacological stability of intravenous solutions, such as high performance liquid chromatography.

\section{Acknowledgements}

We thank the nurses Ariane Ferreira Machado and Lidiane Lopes Reis, doctoral and master's students at the Nursing Graduate Program, Universidade Federal de São Paulo, for their collaboration.

\section{References}

1. Peterlini MAS, Chaud MN, Pedreira MLG. Órfãos de terapia medicamentosa: a administração de medicamentos por via intravenosa em crianças hospitalizadas. Rev Latino-am Enfermagem. 2003;11(1):88-95.

2. Pedreira MLG, Chaud MN. Terapia intravenosa em pediatria: subsídios para a prática da enfermagem. Acta Paul Enferm. 2004; 17(2):222-8.

3. Trissel LA. Drug stability and compatibility issues in drug delivery. In: Trissel LA. Handbook of injectable drugs. 11th ed. Bethesda: American Society of Health-System Pharmacistis; c2001.

4. Stella VJ. Chemical and physical bases determining the instability and incompatibility of formulated and injectable drugs. J Parenter Sci Technol. 1986; 40(4):142-63.

5. Weinstein SM. Plumer's principles and practice of intravenous therapy. $6^{\text {th }}$ ed. Philadelphia: Lippincott; c1997.

6. Pettit J. Assessment of an infant with a peripheral intravenous device. Adv Neonatal Care. 2003; 5(5):230-40.

7. $\mathrm{PH}$ meter info [homepage on the Internet]. $\mathrm{PH}$ meter info [cited 2009 December 4]; [about 1 screen]. Available from: http:// www.ph-meter.info/pH-electrode.

8. Hiseg Instrumentos de Medição Ltda (Brasil). Guia do usuário Extech Instruments - Extik ${ }^{T M} \mathrm{pH}(\mathrm{pH} 100$ \& pH110): Extech Instruments Corporation; 2003. 
9. Machado AF, Pedreira MLG, Chaud MN. Eventos adversos relacionados ao uso de cateteres intravenosos periféricos em crianças de acordo com tipos de curativos. Rev Latino-am Enfermagem. 2008; 16(3):362-7.

10. Phillips LD. Complicações da Terapia Intravenosa. In: Phillips LD. Manual de terapia intravenosa. 2 ed. Porto Alegre (RS): Artmed; c2001. p. 236-98.

11. Micromedex $®$ Healthcare Series [database on the Internet]. Thonsom Healthcare [cited 2009 december 4]. Available from: http://www.thomsonhc.com/hcs/librarian.

12. Wyatt RG, Okamoto GA, Feigin RD. Stability of antibiotics in parenteral solutions. Pediatrics. 1972; 49(1):22-9.

13. Plumridge RL, Rieck AM, Annus TP, Langton SR. Stability of ceftriaxona sodium in polypropylene syringes at $-20,4$, and 20 ${ }^{\circ} \mathrm{C}$. Am J Health-Syst Pharm. 1996; 53:2320-3.

14. Telles PCPF, Cassiani SHB. Administração de medicamentos: aquisição de conhecimentos e habilidades requeridas por um grupo de enfermeiros. Rev Latino-am Enfermagem. 2004; 12(3):533-40.

15. Newton DW. Physicochemical determinants of incompatibility and instability in injectable drugs solutions and admixtures. Am J Hosp Pharm. 1978; 35(10):1213-22.

Received: Nov. $6^{\text {th }} 2008$

Accepted: Dec. $2^{\text {nd }} 2009$ 